\title{
Evaluation of seminal characteristics of Pelibuey and East Friesian rams at two different times of the year
}

\author{
Hernández-Arzola, Marcia P. ${ }^{1}$; Salazar-Ortiz, Juan ${ }^{2}$; Sánchez-del Real, Carlos ${ }^{3}$; \\ Germán-Alarcón, Carlos G. ${ }^{3}$; Gallegos-Sánchez, Jaime ${ }^{1 *}$ \\ 1 Colegio de Postgraduados Campus Montecillo-Ganadería. Carretera México-Texcoco km 36.5, Montecillo, \\ Texcoco, Estado de México, México. C. P. 56230. \\ 2 Colegio de Postgraduados Campus Córdoba. Carretera Córdoba-Veracruz km 348.5. Venta Parada 11, CP \\ 94500 Córdoba, Veracruz. \\ 3 Universidad Autónoma Chapingo. Departamento de Zootecnia. Carretera Federal México-Texcoco km \\ 38.5, Texcoco, Estado de México, México. C. P. 56230. \\ * Corresponding author: gallegos@colpos.mx
}

Gitation: Hernández-Arzola, M P., Salazar-Ortiz, J., Sánchez-del Real, C., Germán-Alarcón, C. G., \& Gallegos-Sánchez, J. (2021). Evaluation of seminal characteristics of Pelibuey and East Friesian rams at two differen times of the year. Agro Productividad. https://doi.org/10.32854/agrop. v14i8.2065

Editor in Chief: Dr. Jorge Cadena Iñiguez

Received: January, 2021.

Accepted: August, 2021.

Agro Productividad, 14(8). August. 2021 pp: 103-109.

This work is licensed under a Creative Commons Attribution-NonCommercial 4.0 International license.

\begin{abstract}
Objective: To determine the changes in seminal quality of Pelibuey and East Friesian rams during the nonbreeding (long days; March-June) and breeding seasons (short days; September-December) at $19^{\circ}$ north latitude.

Design/methodology/approach: To determine changes in seminal quality over time, seminal parameters of rams, collected with an artificial vagina were evaluated over 32 weeks. An analysis of variance was performed with a completely randomized design in a $2 \times 2$ factorial arrangement (breed and season).

Results: No differences were found within breeds or between breeds in the same season in the evaluated seminal parameters; however, differences were reported between seasons in the live weight parameters, lower in the non-reproductive season, in addition to an increased scrotal circumference and mass motility during the reproductive season.

Study limitations/implications: Semen parameters estimation, in field trials, is subjective compared to computerized semen evaluation systems, it is therefore desirable to have extensive experience in semen evaluation at the field level before starting the study. To confirm the results obtained in this study, a new experiment with a larger number of experimental units is suggested.

Findings/conclusions: It is concluded that in the environmental and management conditions, where the seminal evaluation took place, no differences were found between breeds, suggesting that the Pelibuey and East Friesian breeds at $19^{\circ}$ north latitude do not decrease their seminal parameters during the non-breeding season compared to the breeding season. This suggest that these two sheep breeds are able to reproduce, in such conditions, all year round.
\end{abstract}

Keywords: Seminal parameters; Pelibuey; East Friesian. 


\section{INTRODUCTION}

Sheep represent one of the most important livestock species in the world due to the various products derived from them (meat, milk, wool) and its by-products (hair, leather, manure, hooves) (Sánchez-Rodríguez, 2010). To improve productive variables within the herd, reproductive biotechnology has been incorporated in many scientific studies, aiming to understand female and male physiology (Alonso-Aguerrebere, 2018). Studies aimed at solving certain physiological aspects in ram reproduction are focused on making the spermatogenesis process more efficient and thereby improving seminal quality, a very important variable for improving reproductive efficiency in sheep; however, these cellular events related to other environmental factors, such as the photoperiod (Blache et al., 2000; Martin et al., 2010).

A ram is defined as a seasonal breeder and its reproductive activity is regulated by hormones that dynamically integrate the neuroendocrine axis: hypothalamusadenohypophysis-testes; in particular, melatonin and testosterone. Melatonin is synthesized at the pineal glands, the duration of its secretion increases during the reproductive season (short days; autumn-winter) and decreases in the non-reproductive season (long days; spring and summer; northern latitude), regulating the frequency of pulsatile secretion of gonadotropin-releasing hormone (GnRH; Orihuela-Trujillo, 2014). Different sheep breeds show variations in their testosterone secretions throughout the year, and therefore, there are fluctuations in seminal production; however, something important is that, although rams are less susceptible than females to photoperiod and it has been shown that libido decreases during the non-reproductive season, the spermatogenesis process is continuous, although the efficiency with which this cellular event occurs varies due to the effect of photoperiod (Martin et al., 2010; Orihuela-Trujillo 2014).

Other great relevant factors in the different reproductive processes of the rams are the breed and the latitude of origin, since hair breeds, which inhabit latitudes close to the equator, show little seasonality (Arroyo-Ledezma et al., 2007), and breeds from latitudes far from the equator, such as meat and wool-producing breeds, show a marked reproductive seasonality (Malpaux et al., 1997). Thus, the photoperiod, through seasonality and the fluctuations experienced by the spermatogenic process throughout the year, exerts important effects on the physiology of the testis, which will closely relate to the various variables that characterize the ram semen and have a direct impact on seminal quality (Arellano-Lezama, 2015). The objective of the present study was to determine the changes over time in the seminal quality in two ram breeds (Pelibuey vs. East Friesian).

\section{MATERIALS AND METHODS}

\section{Experimental animals}

The study took place from April to July (non-reproductive season; 16 weeks), and from September to December (reproductive season; 16 weeks) of 2020 since the duration of the sperm cycle in rams is approximately 52 to 55 days. The study was carried out at the Sheep and Goat Reproduction Laboratory (LaROCa), at the Colegio de Postgraduados, Campus Montecillos, located at 19²9' north latitude and 98 $53^{\circ}$ ' west latitude and 2240 masl (Garcia, 2004). 
An eight rams group was used, four of the Pelibuey breed (R1) and four of the East Friesian breed (R2), with an average age of $2.5 \pm 0.5$ years and an average initial weight for $\mathrm{R} 1$ of $64.5 \pm 7.4 \mathrm{~kg}$ and $\mathrm{R} 2$ of $70.3 \pm 2.17 \mathrm{~kg}$, these were kept in observation pens, under an intensive management system in a natural photoperiod.

Before starting the study, all rams were dewormed with Ivermectin at a dose of $0.2 \mathrm{mg}$ $\mathrm{kg}^{-1}$ of body weight, vaccinated with BOBACT ${ }^{\circledR} 8$ (MSD Animal Health) at a $2.5 \mathrm{~mL}$ dose per animal, with two applications before the start of the study and with a period of 15 days between the two applications. Also, before the start of the study, behavioral training of the rams was performed, which consisted of taking the sexually inexperienced rams to the mounting area every day for 15 days prior to the start of the study, to familiarize them and teach them to perform the mounting behavior on a restrained ewe.

All experimental animals used in this study were handled following the Mexican Official Standard NOM-062-ZOO-1999 (SAGARPA, 1999) and the manual of practices, and procedures for experimental animals of the Colegio de Postgraduados. During the development of the study, all rams were fed with a base diet at a rate of $3 \mathrm{~kg}$ per animal day $^{-1}$, the diet consisted of $60 \%$ of oat hay and $24 \%$ of sun-cured alfalfa hay, $15 \%$ of a commercial concentrate (Borrega plus: Alimentos Unión Tepexpan ${ }^{\circledR} ; 12 \%$ CP, 40\% FDA, $51 \% \mathrm{NDF}, 2.3 \% \mathrm{EE}$ and $9 \%$ ash) and $1 \%$ of minerals.

\section{Seminal variables and evaluation procedure}

The rams were weighed on a scale (Braunker ${ }^{\circledR}$ YP200S) with a $250 \mathrm{~kg}$ capacity $\pm 100 \mathrm{~g}$, and the scrotal circumference was measured (weekly) with a tape measure (Mellisho, 2010).

The assessed semen variables were classified as qualitative: mass motility, individual progressive motility, appearance and color, as well as quantitative: percentage of live spermatozoa, abnormal spermatozoa (normality), sperm concentration, volume and time to ejaculate.

Immediately after obtaining the samples, using the artificial vagina method, these were analyzed in the laboratory. Semen was evaluated by examining volume and appearance (watery or creamy), as well as color in $15 \mathrm{~mL}$ graduated tubes. To determine the mass motility, a drop of semen was taken with a Pasteur pipette and observed under a brightfield microscope (Carl ZEISS ${ }^{\circledR}$, Primo Star, Microimaging GmbH 37081, Göttingen, Germany. Series-Nr: 3125001511), at a 10X objective, with eyepieces and objectives centered using Köeller illumination, assigning values from 0 (no motility) to 5 (maximum motility, swirling with vigorous mass movement). In the same way, individual progressive motility was evaluated, observing the sperm trajectory ranging from 0 to $100 \%$.

The percentage of live spermatozoa was quantified using a smear stained with the eosin-nigrosin staining technique, the preparations were dried at room temperature and 100 spermatozoa were counted in a single ocular field, considering dead those that were totally or partially stained (Mellisho, 2010). On the smear, the most frequent abnormalities in structure and morphology of 100 cells were observed, the number of spermatozoa with loose heads, coiled tails, loose or double tails, which were the most frequent abnormalities, were determined. Sperm concentration was determined by the 
hemocytometer method, 1:200 dilutions were made. For the sperm count, a semen sample was taken with a hemocytometer up to the 0.5 marks and then the pipette was filled up to the 1.01 mark with Hayem solution, which is a spermicide. The first five drops were manually shaken and removed, the sixth drop was placed in the Neubauer chamber and counted in the four lateral quadrants and the center quadrant of the chamber under a brightfield microscope at 40X magnification (Mellisho, 2010).

\section{Statistical analysis}

An analysis of variance was performed with a completely randomized design, using the PROC MIXED GLM; LSMEANS TUKEY procedure of SAS (2002) with a factorial arrangement (breed and time) for the variables body weight, scrotal circumference, mass motility, individual progressive motility, percentage of live spermatozoa, percentage of sperm abnormalities and time to ejaculate, during 32 weeks per reproductive season, under the following model:

$$
\gamma i_{j k}=\mu+R_{i}+\tau_{j}+A n_{i j k}+F_{k}+R_{i}^{*} F_{k}+\varepsilon_{i j}
$$

where: $\gamma_{i j k}=$ Variable, $\mu=$ Population average, $R_{i}=$ Effect of the $i$-th breed (Pelibuey, East Friesian), $j=$ Effect of the $j$-th week (1..16), $A_{i j k}=$ random effect of the $n$-animal $\sim \mathrm{N}$ $\left(0, \sigma_{a}^{2}\right), F_{k}=$ Effect of the $k$-th time (non-reproductive season, reproductive season), $R_{i}^{*} F_{k}=$ Interaction of the $i$-th race in the $k$-th time, $\varepsilon_{i j}=$ Experimental error, where $\varepsilon_{i j n k} \sim \mathrm{N}$ $\left(0, \sigma^{2}\right)$.

\section{RESULTS AND DISCUSSION}

Table 1 shows the results obtained during the non-breeding season (spring-summer, long days). Table 2 shows the results of the reproductive season (autumn-winter, short days), both expressed as general averages, for the variables body weight, scrotal circumference, volume, sperm concentration, mass motility, \% live spermatozoa and \% normality, no differences were observed (Tables 1 and 2).

According to Aguirre et al. (2004), it is important to evaluate the fertility of rams through a seminal examination, since it determines the reproductive variables that

Table 1. Physical varieties and seminal of two breeds of ram sheep in the non-reproductive season (long days; mean \pm standard deviation).

\begin{tabular}{l|c|c}
\multicolumn{1}{c|}{ Variable } & Breed 1 (Pelibuey) & Breed 2 (East Friesian) \\
\hline Body weight $(\mathrm{kg})$ & $64.5 \pm 7.4^{\mathrm{a}}$ & $82.5 \pm 7.8^{\mathrm{a}}$ \\
\hline Scrotal circumference $(\mathrm{cm})$ & $31.8 \pm 2.25^{\mathrm{a}}$ & $32.0 \pm 1.47^{\mathrm{a}}$ \\
\hline Volume $(\mathrm{mL})$ & $1.0 \pm 0.46^{\mathrm{a}}$ & $0.94 \pm 0.35^{\mathrm{a}}$ \\
\hline Concentration $\left(\times 10^{-9} \mathrm{~mL}^{-1}\right)$ & $3.3 \pm 1.53^{\mathrm{a}}$ & $3.6 \pm 1.50^{\mathrm{a}}$ \\
\hline Masal motility & $3.9 \pm 0.99^{\mathrm{a}}$ & $4.2 \pm 0.80^{\mathrm{a}}$ \\
\hline Live sperm $(\%)$ & $82.3 \pm 10.31^{\mathrm{a}}$ & $83.3 \pm 9.14^{\mathrm{a}}$ \\
\hline Normality $(\%)$ & $92.7 \pm 3.4^{\mathrm{a}}$ & $91.8 \pm 5.5^{\mathrm{a}}$ \\
\hline a, b Rows with different literals represent differences $(\mathrm{P}<0.05)$.
\end{tabular}


Table 2. Physical varieties and seminal of two breeds of ram sheep in the reproductive season (short days; mean \pm standard deviation).

\begin{tabular}{l|c|c}
\hline \multicolumn{1}{c|}{ Variable } & Breed 1 (Pelibuey) & Breed 2 (East Friesian) \\
\hline Body weight $(\mathrm{kg})$ & $71.5 \pm 3.1$ & $77.0 \pm 3.2$ \\
\hline Scrotal circumference $(\mathrm{cm})$ & $32.9 \pm 1.14$ & $32.8 \pm 1.23$ \\
\hline Volume $(\mathrm{mL})$ & $0.84 \pm 0.21$ & $0.72 \pm 0.17$ \\
\hline Concentration $\left(\times 10^{-9} \mathrm{~mL}^{-1}\right)$ & $4.35 \pm 0.19$ & $4.17 \pm 0.20$ \\
\hline Masal motility & $4.4 \pm 0.29$ & $79.5 \pm 0.45$ \\
\hline Live sperm $(\%)$ & $79.4 \pm 2.3$ & $93.1 \pm 1.7$ \\
\hline Normality $(\%)$ & $92.9 \pm 1.4$ & \\
\hline a, b Rows with different literals represent differences $(\mathrm{P}<0.05)$.
\end{tabular}

affect the efficiency of the male that is used as a ram. In the present study, the physical and seminal examination was carried out weekly on all males during 16 weeks from April to July (non-reproductive season or long days), and 16 weeks from September to December (reproductive season or short days). It was found that the animals with the highest average weight were those of the R2 (East Friesian); according to ArteagaCastelán (2007), this breed has an adult weight that ranges the 70 to $90 \mathrm{~kg}$ weight of Pelibuey rams. In the present study, no differences were found in the variables evaluated, analyzing the data obtained comparing the two breeds ( $\mathrm{R} 1$ vs. R2) within epochs (Tables 1 and 2).

There were also no differences in means between seasons (non-breeding vs. breeding season (Table 3), but there was a significance $(\mathrm{p}<0.0032)$ in the weight variable analyzed over time, during the breeding season; for R2, this was expected since it is known that the East Friesian breed has a better daily weight gain, as well as greater body size and development than the Pelibuey breed and that greater weight gain was observed during the reproductive season was also expected since males naturally prepare themselves to begin the period of greater reproduction.

Bernardi et al. (2010) mentioned that animal weight is a variable that influences libido, represented by the display of reproductive behavior, and this also has repercussions on

Table 3. Physical varieties and seminal of two breeds of ram sheep between reproductive season (season 1, non-reproductive season vs. season 2, reproductive season; mean \pm standard deviation).

\begin{tabular}{l|c|c}
\multicolumn{1}{c|}{ Variable } & Season 1 & Season 2 \\
\hline Body weight $(\mathrm{kg})$ & $73.5 \pm 1.99^{\mathrm{a}}$ & $74.2 \pm 1.99^{\mathrm{a}}$ \\
\hline Scrotal circumference $(\mathrm{cm})$ & $31.9 \pm 0.99^{\mathrm{a}}$ & $32.9 \pm 0.99^{\mathrm{b}}$ \\
\hline Volume $(\mathrm{mL})$ & $0.99 \pm 0.08^{\mathrm{a}}$ & $0.78 \pm 0.08^{\mathrm{a}}$ \\
\hline Concentration $\left(\times 10^{-9} \mathrm{~mL}^{-1}\right)$ & $3.4 \pm 0.13^{\mathrm{a}}$ & $4.2 \pm 0.13^{\mathrm{a}}$ \\
\hline Masal motility & $4.1 \pm 0.10^{\mathrm{a}}$ & $4.5 \pm 0.10^{\mathrm{b}}$ \\
\hline Live sperm $(\%)$ & $82.8 \pm 0.79^{\mathrm{a}}$ & $79.4 \pm 0.79^{\mathrm{a}}$ \\
\hline Normality $(\%)$ & $92.3 \pm 0.7^{\mathrm{a}}$ & $93.05 \pm 0.70^{\mathrm{a}}$ \\
\hline a, b Rows with different literals represent differences $(\mathrm{P}<0.05)$.
\end{tabular}


the various physical and seminal variables that comprise a field examination. The oscillations in body weight influence the scrotal circumference diameter, as well as the sperm concentration (SC), presenting, in some studies (Avellaneda et al., 2006; PalaciosMoreno, 2012) significant correlations between these variables. In the present study, statistical differences were found in some variables when analyzing the data between seasons (non-breeding vs. breeding season). For example, in scrotal circumference, there is a significance $(\mathrm{p}<0.0001)$ in the reproductive period. In this regard, Espitia-Pacheco $e t$ al. (2018) mentioned that in males the increase in scrotal circumference is determined as a function of the relationship between age and body weight, since testicular development is closely correlated with body growth and the age of the animal. In the present study, two breeds were used, one of medium size (Pelibuey) and one of large size (East Friesian), which is possibly the reason why the differences were observed. Benítez (2011) also confirmed the importance of scrotal circumference as a variable that must be correlated with body weight, sperm concentration and ejaculate volume. In this regard, sperm concentration in the present study for R1 (Pelibuey) during the non-breeding season was $3.3 \pm 1.53 \times 10^{9} \mathrm{~mL}^{-1}$ and during the reproductive season was $4.35 \pm 0.20 \times 10^{9} \mathrm{~mL}^{-1}$, an increase during the reproductive season, coinciding with the reported $\left(4.051 \pm 0.729 \mathrm{~mL}^{-1}\right)$ by Maza-Gamboa et al. (2015) for Pelibuey rams. While, for the East Friesian breed, in the present study, a mean of $3.6 \pm 1.50 \times 10^{9} \mathrm{~mL}^{-1}$ and in the reproductive season of $4.17 \pm 0.20 \times 10^{9} \mathrm{~mL}^{-1}$ being higher than that reported by Delgado-Cásares (2013) who obtained an average of $2.0 \times 10^{9} \mathrm{~mL}^{-1}$, in wool breeds. It is important to mention that most rams of the different sheep breeds produce semen throughout the year; however, there is a decrease in semen production and sexual activity during the spring months (non-reproductive season, northern latitude). It is also mentioned that the efficiency with which spermatogenesis is carried out is evaluated with various physical and andrological variables such as body weight and scrotal circumference, which are related to the variables that characterize semen. In the present study, it was found that the variable mass motility $(p<0.0001)$ is higher in the reproductive season compared to the non-reproductive season. According to Hafez and Hafez (2004), a very good sperm concentration ranges from $3.5 \times 10^{9}$ to $6.0 \times 10^{9}$ $\mathrm{mL}^{-1}$ during the reproductive season. In this study the sperm concentrations, both in the non-reproductive and reproductive seasons, are within the aforementioned ranges; that is, the males used in this study had very good sperm concentrations throughout the year, possibly due to the management provided in the laboratory, good supervision in feeding and sanitation.

\section{GONGLUSION}

It is concluded that under the environmental and management conditions, where the seminal evaluation was carried out in this study, no differences were found between breeds, suggesting that the Pelibuey and East Friesian breeds, located at $19^{\circ}$ north latitude, do not present a decrease in seminal parameters during the non-breeding season compared to the breeding season, which suggests that these two breeds of ram sheep are capable of reproducing, under these conditions, all year round. 


\section{REFERENGES}

Aguirre, V., Orihuela, A., Vázquez, R. (2004). Comportamiento de algunas variables usadas como un procedimiento para estimar la capacidad sexual (fertilidad) del carnero. Investigación Agropecuaria, 1(1), 81-85.

Alonso-Aguerrebere, J.I. (1981). Manejo de la reproducción en el ovino. Ciencia Veterinaria, 3(13), 434-463.

Arellano Lezama, T. (2015). La nutrición y su efecto en las células testiculares del carnero. Tesis doctoral, Colegio de Postgraduados. México.

Arroyo-Ledezma, J., Gallegos-Sánchez, J., Villa-Godoy, A., Berruecos, J.M., Perera, J., Valencia J. (2007). Reproductive activity of Pelibuey and Suffolk ewes at $19^{\circ}$ north latitude. Animal Reproduction. Science, 102, 24-30.

Arteaga-Castelán, J.D. (2007). Razas ovinas en México, Asociación Mexicana de Criadores de Ovinos. Disponible en: https://uno.org.mx/razas_ovinas/catalogo_razas.pdf

Avellaneda, Y., Rodríguez, F., Grajales, H., Martínez, R. \& Vásquez, R. (2006). Determinación de la pubertad en corderos en el trópico alto colombiano por características corporales, calidad del eyaculado y valoración de testosterona. Livestock Research for Rural Development, 18(10). Disponible en: http://www. lrrd.cipav.org.co/lrrd18/10/avel18138.htm

Benítez, D.M. (2011). Circunferencia escrotal y parámetros de calidad seminal en caprinos de las razas Bóer, Anglo nubian y Criollos de la Provincia de Formosa. Tesis, Universidad Nacional de Nordeste. Facultad de Ciencias Veterinarias. Argentina.

Bernardi, S., Brogliani, G., Oyarzabal, M.I. (2010). Estructura testicular y calidad seminal en ratones seleccionados por peso. International Journal of Morphology, 28(3), 673-680. Doi: 10.4067/S071795022010000300004

Blache, D., Chagas, L.M., Blackberry, M.A., Vercoe, P.E., Martin, G.B. (2000). Metabolic factors affecting the reproductive axis in male sheep. Journal of Reproduction and Fertility, 120(1), 1-11. Doi: :10.1530/ $\operatorname{reprod} / 120.1 .1$

Delgado-Cásares, B.E. 2013. Evaluación espermática de semen de ovino tratado por la técnica de gradiente de densidad. Disponible en: http://repositorio.urp.edu.pe/handle/urp/589.

Espitia-Pacheco, A., Montes-Vergara, D., Lara-Fuenmayor, D. (2018). Evaluation of testicular development and morphometrics measurements in Colombian hair sheep. Agronomía Mesoamericana, 29(1),165-175.

García, E. (2004). Modificaciones al Sistema de clasificación climática de Köppen. Instituto de Geografía, Universidad Nacional Autónoma de México.

Hafez, E.S.E., Hafez, B. (2004). Reproducción e inseminación artificial en animales. México: McGraw-Hill Inteamericana.

Malpaux, B., Viguié, C., Skinner, D.C., Thiéry, J.C., Chimineau, P. (1997). Control of the circannual rhythm of reproduction by melatonin in the ewe. Brain Research Bulletin, 44,(4). 431-438. Doi: 10.1016/s03619230(97)00223-2

Martin, G.B., Blache, D., Miller, D.W., Vercoe, P.E. (2010). Interactions between nutrition and reproduction in the management of the mature male ruminant. Animal, 4(7): 214-226. Doi: 10.1017/ S1751731109991674

Maza-Gamboa, J., Navarrete-Sierra, L.F., Aguilar- Loría, A., Zamora- Bustillos, R., Magaña-Sevilla, H. (2015). Calidad seminal en ovinos Pelibuey con inclusión de Hibiscus rosasinensis en la dieta. Nova Scientia, 7(15), 33-48. Doi: 10.21640/ns.v7i15.252

Mellisho, E. (2010). Manual de laboratorio de reproducción animal. Disponible en: http://tarwi.lamolina.edu. pe/ emellisho/reproduccionarchivos/practica\%204-eval-semen.pdf

Orihuela-Trujillo, A. (2014). La conducta sexual del carnero: Revisión. Revista Mexicana de Ciencias Pecuarias, 5(1), 49-89. Doi: 10.22319/rmcp.v5i1.3217

Palacios-Moreno, N., González-Mendoza, D.F. (2012). Correlación entre diámetro testicular y calidad espermática en ovinos criollos del Municipio de Soracá, Boyacá. Conexión Agropecuaria JDL, 2(2): 45-55.

SAGARPA. (1999). NORMA Oficial Mexicana NOM-062-ZOO-1999, Especificaciones técnicas para la producción, cuidado y uso de los animales de laboratorio. Disponible en: https://www.fmvz.unam.mx/ fmvz/principal/archivos/062ZOO.PDF

Sánchez-Rodríguez, M. (2010) Curso: Producción y bienestar animal, pequeños rumiantes. Córdoba. Universidad de Córdoba. Asociación Iberoamericana de Zootecnia.

SAS. 2011. JMP. Statistic Visual. Version 9.2. institute inc, campus Drive. Cary. NC. 27517. 